\title{
Diallel Analysis of Fruit Water Absorption in Tomato, a Contributing Factor in Postharvest Decays
}

\author{
S.M. Smith and J.W. Scott ${ }^{1}$ \\ University of Florida, GCREC, Horticultural Sciences Department, 14625 County Road 672, \\ Wimauma, FL 33598 \\ J.A. Bartz \\ University of Florida, Plant Pathology Department, P.O. Box 110680, Gainesville, FL 32611
}

S.A. Sargent

University of Florida, Horticultural Sciences Department, P.O. Box 110690, Gainesville, FL 32611

ADDITIONAL INDEX wORDs. bacterial soft rot, Erwinia carotovora, Lycopersicon esculentum, postharvest disease resistance, Solanum lycopersicum

\begin{abstract}
Harvested tomato (Solanum lycopersicum L.) fruit can absorb water via stem scar tissues. Decay incidence \{bacterial soft rot (Erwinia carotovora Jones), sour rot (Geotrichum candidum Link), bacterial sour rot [Leuconostoc mesenteroides (Tsenkovskii) van Tieghem ssp. mesenteroides], and certain species of Lactobacillus Beijerinck $\}$ has been positively linked with the degree of water absorption. Previous studies have shown that cultivars differ in their tendencies to take up water during a simulation of packinghouse handling procedures. The inheritance of water absorption tendency was examined in two seasons of tests where six inbred tomato lines were intercrossed to develop a complete diallel. Following harvest at the mature-green stage, fruit were weighed, submerged in water for 2 min, and then reweighed to determine water absorption. Parental lines were tested in three seasons. Two parental lines, Fla. 7776 and Fla. 7946, were always in the low-absorption grouping, and NC84173 also had relatively low absorption. Fla. 8059 and Fla. 7777 were always in the high-absorption group, and Fla. 8000 tended to have high absorption. General combining ability for the low water absorption fruit characteristic was significant for both seasons with a higher level of significance in the spring over the fall season $(P \leq 0.001$ and $P \leq 0.05$, respectively), while specific combining ability was not significant for either season. Thus, the low water absorption fruit characteristic appears to be additively inherited. Accurate knowledge of parental absorption should allow prediction of hybrid performance. None of the hybrids absorbed unexpected amounts of water over both seasons. Reciprocal effects were significant $(P \leq 0.05)$ for fall, and maternal effects were significant $(P \leq 0.05)$ in spring. However, there was no general trend in water absorption due to the direction of the cross and thus no clear evidence for cytoplasmic inheritance. Water absorption was much greater in spring than in fall. Based on previous observations, the greater absorption in spring was due to higher field temperatures. Because of such environmental effects, parent lines should be replicated and tested over several seasons to accurately assess their relative water absorption. Crosses between consistently low water absorption parents should provide low-absorption hybrids, but testing of hybrids before release is suggested to verify this.
\end{abstract}

Bacterial soft rot causes significant losses to many fresh vegetables, including fresh market tomatoes. This disease is sometimes seen in the field and is not uncommon when a crop has endured persistently wet conditions. The disease can develop within a day or two after the fruit has been inoculated, and because the pathogen is strictly a wound invader, the harvest and subsequent packinghouse handling are particularly hazardous periods. Two other types of decay pathogens have been associated with wet fields: Geotrichum candidum, which is the cause of sour rot, and lactic acid bacteria (Leuconostoc mesenteroides ssp. mesenteroides and certain Lactobacillus species), which cause similar types of decay. Major postharvest losses can occur readily. Buyers may refuse to purchase loads

Received for publication 27 Apr. 2007. Accepted for publication 18 Sept. 2007. The authors thank Dolly Cummings and Rosa Ayala for their technical assistance and the Florida Tomato Committee for partial monetary support of this research.

${ }^{1}$ Corresponding author. E-mail: jwsc@mail.ifas.ufl.edu. with cartons that come out of the ripening room with visible wet spots (from decaying fruit ooze). Upon arrival at the receiver, shipments may be rejected outright or prices required to be lowered when decay incidence exceeds grade standards. Moreover, excessive decay problems often jeopardize the sale of future tomatoes from a packinghouse.

Fruit become infected when they absorb contaminated water or when pathogens enter wounds. The latter is a particularly egregious form of inoculation because the pathogen becomes internalized in the fruit through the stem scar when fruit are immersed in a packinghouse dump tank, which washes off the fruit and eliminates most pathogens (Bartz, 1991). Several milliliters of water can enter a single fruit, and the fruit's internal cells are not protected from attack. This water absorption is driven by principles described in the general gas law (Showalter and Bartz, 1979). Changes in the pressure of an ideal gas in a closed container of constant volume are directly proportional to a change in temperature of the gas. Tomatoes are a type of container, which is not completely closed, that 
generally has a constant gas volume due to numerous airspaces that are filled with gases. As the temperature of the fruit decreases, the internal gas pressure also decreases creating a partial vacuum, which draws water into the fruit (Showalter and Bartz, 1979). A second principle involved with tomatoes and water handling systems is that the pressure of water on the external surface of the fruit governs how much water penetrates natural openings or wounds. Fruit struck by strong streams of water, such as in the unloading of gondolas or fruit forced deeply into dump tanks by the weight of the unloaded fruit, are more likely to absorb water. Thus, packinghouse managers have been advised to maintain dump tank water at a temperature higher than that of the fruit to limit temperature-driven absorption and to avoid overcrowding the dump tank to minimize hydrostatic forces on the fruit. If the fruit surfaces or the dump tank water are contaminated with decay pathogens, then any absorption of the surrounding water would be accompanied by an internalization of those pathogens by the fruit (Bartz and Showalter, 1981). The greater the number of pathogens getting into the fruit, the faster the fruit will develop the disease (Berger and Bartz, 1982).

Certain tomato cultivars are considered tolerant to bacterial soft rot because the disease is slower to develop at inoculated wounds as compared with completely susceptible cultivars (Bartz and Crill, 1972). Other cultivars have a tolerance because of their reduced tendency to absorb water through the stem scar during handling at a packinghouse (Bartz, 1991). This type of tolerance extends to other water-borne decay pathogens and is a factor in food-safety concerns as well (Bartz, 2006). 'Solar Set', 'Sunny', 'Horizon', and 'Equinox' appear to have both types of tolerance. Water absorption was measured and wound inoculation tests were performed in Fall 1987 and Spring 1988 for 'Solar Set' and in Spring 1983 for 'Sunny' and 'Horizon' (Scott et al., 1985, 1989). Similar tests were performed, but data were not presented for the 'Equinox' tests (Scott et al., 1995).

Fruit tolerance to soft rot development does not appear to be as important in postharvest decay development as the reduced water absorption characteristic. For example, 'Florida MH-1' was released as a soft rot-tolerant cultivar (Crill et al., 1971), and Bartz et al. (1975) reported that this cultivar was slower to develop bacterial soft rot in wound inoculation tests than 'Walter', a more commonly grown cultivar at that time. However, Bartz (1991) later reported on tests with five commonly grown cultivars in 1983-1984, noting that 'Florida MH-1' ranked the most tolerant after wound inoculation but the least tolerant after inoculation by immersion in water with a temperature differential. In the latter test, fruit of 'Florida $\mathrm{MH}-1$ ' absorbed nearly four times more aqueous cell suspension of Erwinia carotovora than did those of the least absorptive cultivar, 'Burgis', and developed six times more disease $(60 \%$ vs. $10 \%)$ by $3 \mathrm{~d}$ postinoculation. In contrast, the wound-inoculation test led to a disease incidence of $12 \%$ in 'Florida MH-1' vs. $47 \%$ in 'Burgis'. Clearly, the increased level of inoculation for 'Florida MH-1' fruit overwhelmed their innate resistance to bacterial soft rot development. Because currently all fresh market tomatoes are washed in the dump tank, the most effective way to decrease the chance of infection is to grow cultivars with fruit that resist water absorption through their stem scars and use good cultural and sanitation practices (Mahovic et al., 2007).

Bartz (1991) immersed 10 cultivars into water containing a $10^{6} \mathrm{cfu}$ suspension of $E$. carotovora for $2 \mathrm{~min}$. Water absorption $(0.38 \%$ of initial fruit weight) and soft rot infection $(96 \%)$ for
'BL4049' were significantly greater than the respective water absorption (0.08\%) and soft rot infection (58\%) for 'Sunny'. These data have been supported under commercial conditions when packinghouses have had greater soft rot problems with cultivars known to take up higher amounts of water than those with less water absorption (J.W. Scott, personal communication).

More recently, Bartz and Scott (2005) tested several different cultivars grown in Florida in three locations. The results showed that the widely grown cultivars Florida 91 and Florida 47 ranked among the highest in each test for the amount of water absorption. 'Solar Fire' and 'Sebring' ranked among the lowest for water absorption in each test. The amount of water infused by 'Sanibel' and 'Solar Set' was intermediate in these tests. However, there is no information on the inheritance of stem scar water absorption. This information would be useful for avoiding the use of breeding lines with high water absorption tendencies in cultivar development programs. Fruit with high water absorption tendencies would likely be more prone to postharvest decays as well as absorbing fruit safety hazards (Wei et al., 1995; Zhuang et al., 1995).

Modern tomato cultivars are nearly all hybrids. Hybrids facilitate the combining of dominant disease resistance genes, allow gene complementation, and have numerous other advantages (Scott and Angell, 1998). Because hybrids are widely grown in Florida and elsewhere, a diallel analysis seemed appropriate to develop useful inheritance information on fruit water absorption tendencies. Herein we report on a 2 -year study on the inheritance of fruit water absorption tendencies using a diallel analysis.

\section{Materials and Methods}

Diallel Construction. The six parents chosen for this study were selected from a preliminary study in Spring 2004, when 58 inbreds and hybrids were assayed for fruit water absorption tendency. The parents selected represent an array of absorption levels and are listed in order from low to high on the basis of their Spring 2004 water absorption, presented later in this report; NC84173, Fla. 7946, Fla. 7776, Fla. 8000, Fla. 8059, and Fla. 7777; henceforth, the prefix "Fla." will not be used. Besides representing a broad range of water absorption, the lines are being used as parents of commercial hybrids or near commercial hybrids. All of the lines were reciprocally crossed to create a complete diallel which was grown in Fall 2005 and Spring 2006 at the Gulf Coast Research and Education Center (GCREC) in Wimauma, FL. Seeds for crosses $7946 \times 7776$ and $8059 \times 7777$ were not available in Fall 2005. To perform the analysis for the complete diallel, the amount of water absorbed by these two hybrids was estimated using the missing plot technique for several missing values (Steel and Torrie, 1980).

SPRING 2004. A preliminary study was conducted to determine the water absorption values of many genotypes including the parents used in the current study. Seeds were sown on 18 Feb. 2004 and seedlings were transplanted on 26 Feb. at GCREC, Bradenton, FL. The transplants were planted in the field on 28 Mar. Parents and hybrids were grown in a completely randomized block design with two blocks and five plants per plot. Plants were grown in raised beds in Eau Gallie sandy soil and fumigated with methyl bromide:chloropicrin, $67: 33$ at $392 \mathrm{~kg} \cdot \mathrm{ha}^{-1}$. Banded fertilizer was applied in grooves on the bed shoulder, and then the beds were covered with black polyethylene mulch. The total fertilizer applied was 
equivalent to $316 \mathrm{~kg} \cdot \mathrm{ha}^{-1} \mathrm{~N}, 34 \mathrm{~kg} \cdot \mathrm{ha}^{-1} \mathrm{P}$, and $364 \mathrm{~kg} \cdot \mathrm{ha}^{-1} \mathrm{~K}$. The beds were $81 \mathrm{~cm}$ wide and $20 \mathrm{~cm}$ high and were spaced on 152-cm centers with six beds between seepage irrigation/ drainage ditches, which were on $1250-\mathrm{cm}$ centers. All other procedures were the same as in Fall 2005. Only data from the six parental lines listed previously are presented.

Fall 2005. The seeds were sown in an inert medium, Black Beauty spent coal (Reed Minerals Div., Highland, IN), on 1 Aug. 2005. The seedlings were transplanted on 9 Aug. into Speedling trays $\left(3.8 \mathrm{~cm}^{3}\right.$ cell size) (Speedling, Sun City, FL) in the greenhouse. The plants were transplanted in the field at the relocated GCREC in Wimauma, FL, on 12 Sept., and plants were reset as needed on 15 and 20 Sept. Parents and hybrids were grown in a completely randomized block design with three blocks and 10 plants per plot. Plants were grown on raised beds in a mixture of Myakka, Haplaquents, and St. Johns sandy soil that were $25 \mathrm{~cm}$ high, $71 \mathrm{~cm}$ wide at the top, and $81 \mathrm{~cm}$ wide at the base. Plants were spaced $46 \mathrm{~cm}$ apart within plots that were $92 \mathrm{~cm}$ apart in rows with $152 \mathrm{~cm}$ between rows. The beds were fumigated with $67 \%$ methyl bromide: $33 \%$ chloropicrin at 197 $\mathrm{kg} \cdot \mathrm{ha}^{-1}$ and covered with white plastic mulch. A granular fertilizer consisting of $293 \mathrm{~kg} \cdot \mathrm{ha}^{-1} \mathrm{~N}$ and $486 \mathrm{~kg} \cdot \mathrm{ha}^{-1} \mathrm{~K}$ was placed in two bands on top of the beds $20 \mathrm{~cm}$ from the plants. The plants were staked and tied and irrigated by seepage ditches between each three of 12 plant beds. Plants were sprayed with pesticides as needed throughout the season (Olson et al., 2005).

Spring 2006. Seeds were sown on 6 Feb. 2006, and seedlings were transplanted on 20 Feb. into Speedling trays in the greenhouse. The plants were transplanted in the field on 20 Mar., and plants were reset as needed on 23, 27, and 28 Mar. Parents and hybrids were grown in a completely randomized block design with three blocks and eight plants per plot. Plants were grown in raised beds with a mixture of Myakka and Melabar sandy soil. The beds were covered with silver plastic mulch. The plants were fertilized with a total of $169 \mathrm{~kg} \cdot \mathrm{ha}^{-1} \mathrm{~N}$, $37 \mathrm{~kg} \cdot \mathrm{ha}^{-1} \mathrm{P}$, and $210 \mathrm{~kg} \cdot \mathrm{ha}^{-1} \mathrm{~K}$ throughout the season through drip irrigation. All other procedures were the same as in Fall 2005.

Fruit HARVEST. Parent and hybrid lines in each block were randomly split into four harvest groups of about seven to nine genotypes to prevent confounding the results due to unequal harvest to submersion intervals that could lead to variable stem scar drying between genotypes (Smith et al., 2007). Twelve fruit per plot with epidermis intact were hand-harvested into crates with the stems removed at the mature green stage on 19, 20, and 22 Dec., respectively, in Fall 2005 and on 19, 20, and 21 June, respectively, in Spring 2006. Once the fruit were brought into the laboratory, each genotype was split into three subsets of four fruit. The fruit were then wiped off with a towel and labeled using a permanent marker with their block, line identification, and sample numbers.

Fruit immersion. Each subset of four fruit was weighed on a scale to find the initial weight. After this, 36 fruit at a time (nine subsets selected randomly) were put into a pressure cooker containing water. Immersion tests were repeated until all fruit from each harvest group were immersed. Because there were three blocks, a total of 36 fruit per genotype were immersed for data analysis. A pressure cooker was used to simulate what the fruit are exposed to in a commercial dump tank. The water was $30{ }^{\circ} \mathrm{C}$, and the fruit were at room temperature $\left(22^{\circ} \mathrm{C}\right)$. All of the fruit were immersed in $\approx 15 \mathrm{~cm}$ of water by placing a steel plate and $0.95 \mathrm{~kg}$ weight over the top layer of fruit. The fruit were pressurized for $2 \mathrm{~min}$ at $11,921.3 \mathrm{~Pa}$ of pressure under $1-1.3 \mathrm{~m}$ water head pressure. After 2 min of pressure, the fruit were removed from the pressure cooker. Overall, the procedure required fruit to be immersed in water for $\approx 4 \mathrm{~min}$. When removed, the fruit were put onto trays covered with towels, dried off by hand with towels to eliminate any moisture on the fruit, and separated into their respective groups of four. After all of the fruit were dried, each group was reweighed and the weight gain was determined by subtracting the weight before immersion from the weight after immersion (Bartz, 1988).

Statistical analysis. To account for fruit size differences, the percentage weight gain was calculated and this was then transformed using the arcsine square root method because the percentage weight gain data were less than 10\% (Steel and Torrie, 1980). Thus, the percentage weight increase $=$ weight increase/initial weight $\times 100$, which was then transformed by the square root of $(0.5+$ percentage weight increase $)$. The data were analyzed using the transformed data but the data are presented as the \% weight increase for clarity. Data were subjected to analysis of variance, a Duncan's multiple range test (DMRT), and the contrast procedure using SAS (version 9.0; SAS Institute, Cary, NC). The least-square means procedure was used to test the effects of fruit weight on water absorption (Ott and Longnecker, 2004). Griffing's Method 1 (complete diallel including the parents), Model 1 was used in Diallel-SAS05 to determine the effects of the general combining ability, specific combining ability, reciprocal, maternal, and nonmaternal effects (Griffing, 1956; Zhang et al., 2005).

\section{Results}

Both environment (growing season) and genotype significantly affected fruit water absorption (Table 1). However, the interaction between environment and genotype was significant, indicating the genotypes did not behave similarly between seasons. Therefore, the data were analyzed separately for each season. Fruit weight also significantly affected water absorption for most parents and hybrids, where large fruit absorbed more water than small fruit during both seasons (data not shown). There were very few instances where larger fruit absorbed small amounts of water. However, because our analyses were based on weight gain per gram of fruit, fruit weight did not affect genotypes or seasonal comparisons.

Parents were evaluated in three seasons including the preliminary experiment in Spring 2004. In that season, fruit of parents NC84173 and 7946 absorbed significantly less water than 7777 and 8059, while 7776 absorbed significantly less water than 8059 . The absorption values for fruit of 8000 were not significantly different from any other genotypes (Table 2). In Fall 2005, fruit of parents 7776 and NC84173 absorbed significantly less water than those of 8000 , and there were no other significant differences. In Spring 2006, fruit of 7946 absorbed significantly less water than those of NC84173, 8000,

Table 1. Analysis of variance for water absorption of tomato fruit from a complete diallel grown in two seasons, Fall 2005 and Spring 2006.

\begin{tabular}{lrccc}
\hline Source & df & Sum of squares & Mean square & $F$ \\
\hline Season & 1 & 1.737 & 1.737 & $613.84^{* * *}$ \\
Block (Season) & 4 & 0.023 & 0.006 & 2.00 \\
Genotype & 35 & 0.362 & 0.010 & $3.66^{* * *}$ \\
Season $\times$ Genotype & 35 & 0.463 & 0.013 & $4.67^{* * *}$ \\
\hline ***
\end{tabular}

${ }^{* *}$ Significant differences at $P \leq 0.001$. 
7777, and 8059; 7776 fruit absorbed significantly less water than those of 8000,7777 , and 8059; NC84173 fruit absorbed significantly less water than those of 7777 and 8059; and 8000 fruit absorbed significantly less water than those of 8059 . For all seasons, fruit of 7776 and 7946 were always in the lowestabsorption group while fruit of NC84173 generally had low water absorption but was slightly greater in Spring 2006. Parents 8059 and 7777 were always in the highest-absorption group while fruit of 8000 had relatively high absorption over all three seasons.

General combining ability (GCA) was significant for both seasons and had higher significance in spring (Table 3). Specific combining ability (SCA) was not significant for either season. Thus, water absorption appeared to be inherited additively. When low water absorption parents were intercrossed, the hybrids had relatively low water absorption for each season (Tables 4 and 5). Overall, as the amount of water absorbed by the parents increased, water absorption by the hybrids tended to increase. This is more easily seen in spring, where GCA was more pronounced (Table 5).

Reciprocal effects (REC) were significant in fall but not in spring. Maternal effects (MAT) were significant in spring but not in fall. Nonmaternal effects (NMAT) did not affect water absorption for either season (Table 3). In fall, three of the reciprocal hybrids absorbed significantly different amounts of water: $7776 \times 7777, \mathrm{NC} 84173 \times 7946$, and $7777 \times 8000$ (Table 6). Although these three hybrids all had significantly less

Table 2. Weight increase (\%) due to water absorption for fruit of tomato parents used to create a complete diallel in Fall 2005 and Spring 2006.

\begin{tabular}{lccc}
\hline & \multicolumn{3}{c}{ Weight increase $(\%)^{\mathrm{z}}$} \\
\cline { 2 - 4 } Parent & Spring 2004 & Fall 2005 & Spring 2006 \\
\hline NC84173 & $0.17 \mathrm{a}^{\mathrm{y}}$ & $0.05 \mathrm{a}^{\mathrm{x}}$ & $0.39 \mathrm{bc}$ \\
Fla. 7946 & $0.20 \mathrm{a}$ & $0.10 \mathrm{ab}$ & $0.19 \mathrm{a}$ \\
Fla. 7776 & $0.25 \mathrm{ab}$ & $0.04 \mathrm{a}$ & $0.23 \mathrm{ab}$ \\
Fla. 8000 & $0.27 \mathrm{abc}$ & $0.17 \mathrm{~b}$ & $0.43 \mathrm{~cd}$ \\
Fla. 7777 & $0.40 \mathrm{bc}$ & $0.12 \mathrm{ab}$ & $0.64 \mathrm{de}$ \\
Fla. 8059 & $0.43 \mathrm{c}$ & $0.10 \mathrm{ab}$ & $0.66 \mathrm{e}$ \\
\hline
\end{tabular}

$\bar{z}($ Weight increase/initial weight $) \times 100$.

${ }^{y}$ Means in columns with the same letter are not significantly different by least-squares method test at $P \leq 0.05$ using the percentages transformed by the arcsine square root method.

${ }^{x}$ Means in columns with the same letter are not significantly different by Duncan's multiple range test at $P \leq 0.05$ using the percentages transformed by the arcsine square root method.

Table 3. Estimates of general combining ability (GCA), specific combining ability (SCA), and reciprocal (REC), maternal (MAT), and nonmaternal (NMAT) effects for tomato water absorption grown in a complete diallel over two seasons.

\begin{tabular}{llrccc}
\hline Season & Source & df & Sum of squares & Mean square & $F$ \\
\hline Fall 2005 & GCA & 5 & 0.0985 & 0.0197 & $2.38^{*}$ \\
& SCA & 15 & 0.1454 & 0.0097 & 1.17 \\
& REC & 15 & 0.2280 & 0.0152 & $1.84^{*}$ \\
Spring 2006 & MAT & 5 & 0.0716 & 0.0143 & 1.73 \\
& NMAT & 10 & 0.1555 & 0.0156 & 1.88 \\
& GCA & 5 & 0.4233 & 0.0847 & $24.55^{* * *}$ \\
& SCA & 15 & 0.0444 & 0.0030 & 0.86 \\
& REC & 15 & 0.0837 & 0.0056 & 1.62 \\
& MAT & 5 & 0.0438 & 0.0088 & $2.54^{*}$ \\
& NMAT & 10 & 0.0407 & 0.0041 & 1.18 \\
\hline
\end{tabular}

${ }^{*, * * *}$ Significant differences at $P \leq 0.05$ and $P \leq 0.001$, respectively. absorption when the low-absorption parent was the female, many of the nonsignificant differences were in the opposite direction (Table 6). Thus, maternal effects were not significant in the fall. For spring, the significant maternal effects were due to the two significantly different reciprocals having more absorption when the low-absorption parent was the female, while the majority of nonsignificantly different hybrids varied in the same direction. If the REC were important, they would seem likely to occur where there were significant parental differences, but this was not evident. There are instances where the parents were found to be significantly different during both seasons, one season, or neither season (Table 6). Even though the parents were significantly different, the reciprocal hybrids were not always found to be significantly different. Sometimes when the parents were not significantly different, the reciprocal hybrids were found to be significantly different. In only a few cases, the parents and hybrids were found to be significantly different in the same season. For both seasons, when the two lowest-absorption parents were crossed, the hybrids absorbed the least amount of water when compared with all other hybrids for each season. In fall, $7776 \times$ NC84173 hybrids absorbed the least amount of water in both directions. In spring when 7776 was crossed with 7946, the hybrids absorbed the least amount of water in both directions.

The amount of water absorbed by the fruit was much greater in spring as compared with fall (Table 6). Comparing some environmental and cultural conditions for the two seasons may help explain why this occurred. Whereas rainfall was negligible and the relative humidity values were comparable, the mean temperature for the 2 weeks preceeding harvest through the end of harvest for spring $\left(26.3^{\circ} \mathrm{C}\right)$ was much higher as compared with fall $\left(14.7^{\circ} \mathrm{C}\right)$, and this effect on fruit growth may be an important factor in water absorption (data not shown).

\section{Discussion}

At the University of Florida, tomato cultivars have been tested for water absorption for over 30 years, while there has been no published information on such testing in other regions. The reasons for the Florida tests are due to the threat of bacterial soft rot, which is the most important postharvest disease for tomatoes grown in humid production areas due to its explosive reproduction (Bartz, 1991). Bacterial soft rot is not an important problem in dry climates such as in the California or Mediterranean regions. However, the recent linkage of tomatoes to food safety concerns and, in particular, to internalized inocula is evidence that whenever tomatoes are handled in or exposed to water, the water absorption tendencies of the fruit should be an important concern for all fresh-market production regions. Until now, there has been no inheritance information available to assist tomato breeders in developing low water absorption, large-fruited tomato cultivars for warm, humid growing regions, such as Florida and the southeastern United States. Development of lowabsorption cultivars is useful in limiting soft rot and other postharvest diseases. 
Table 4. Water absorbed by tomato parents and hybrids used to form a complete diallel in Fall 2005.

\begin{tabular}{|c|c|c|c|c|c|c|c|c|c|}
\hline & \multicolumn{9}{|c|}{ Water absorbed $(\%)^{z}$} \\
\hline & & & \multicolumn{6}{|c|}{ Male } & \\
\hline & & & Fla. 7776 & NC84173 & Fla. 7946 & Fla. 8059 & Fla. 7777 & Fla. 8000 & \\
\hline & & & 0.04 & 0.05 & 0.10 & 0.10 & 0.12 & 0.17 & Mean \\
\hline \multirow{7}{*}{ Female } & Fla. 7776 & 0.04 & - & 0.05 & 0.09 & 0.10 & 0.06 & 0.14 & 0.09 \\
\hline & NC84173 & 0.05 & 0.04 & - & 0.02 & 0.06 & 0.05 & 0.15 & 0.06 \\
\hline & Fla. 7946 & 0.10 & $0.08^{\mathrm{y}}$ & 0.13 & - & 0.08 & 0.14 & 0.09 & 0.11 \\
\hline & Fla. 8059 & 0.10 & 0.09 & 0.09 & 0.07 & - & $0.11^{\mathrm{y}}$ & 0.14 & 0.10 \\
\hline & Fla. 7777 & 0.12 & 0.15 & 0.13 & 0.12 & 0.11 & - & 0.03 & 0.11 \\
\hline & Fla. 8000 & 0.17 & 0.12 & 0.12 & 0.05 & 0.15 & 0.17 & - & 0.12 \\
\hline & Mean & & 0.10 & 0.10 & 0.07 & 0.10 & 0.11 & 0.11 & 0.10 \\
\hline
\end{tabular}

$\bar{z}$ (weight increase/initial weight) $\times 100$.

${ }^{y}$ Absorption values estimated using the missing plot technique for several missing values (Steel and Torrie, 1980).

Table 5. Water absorbed by tomato parents and hybrids used to form a complete diallel in Spring 2006.

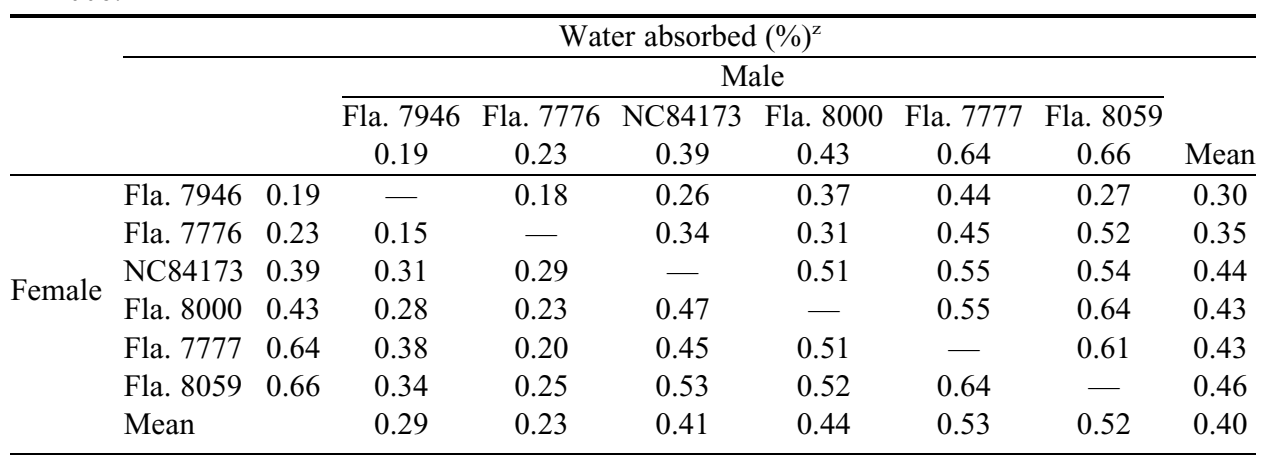

$\overline{\mathrm{z}}$ (weight increase/initial weight) $\times 100$.
In the present study, the significant GCA effects and insignificant SCA effects suggested additive inheritance. Based on this, no hybrid had unexpectedly high or low water absorption over both seasons, although some hybrids may have had an unexpected level of water absorption in a given season due to unknown effects. Thus, knowledge of parental water absorption appears to be a good predictor of hybrid performance, and combining two low-absorption parents provides hybrids with the lowest water absorption, which is evident in the present study. On average, the parents in the low-absorption group (7946, 7776, and NC84173) had percentage weight increases of 0.06 and 0.27 in the fall and spring, respectively while parents in the high-absorption group (8059, 7777, and 8000) had respective percentage weight increases of 0.13 in the fall and 0.58 in the spring. Hybrids between parents in the low group had percentage weight increases of 0.07 in the fall and 0.26 in the spring, which are similar to the average percentage weight increase of their parents. Hybrids between a low-absorption and a high-absorption parent had

Table 6. Water absorption for reciprocal tomato hybrids in Fall 2005 and Spring 2006.

\begin{tabular}{|c|c|c|c|c|c|}
\hline & & \multicolumn{4}{|c|}{ Water absorption $(\%)^{z}$} \\
\hline & & \multicolumn{2}{|c|}{ Fall 2005} & \multicolumn{2}{|c|}{ Spring 2006} \\
\hline \multicolumn{2}{|c|}{ Parents $^{\mathrm{y}}$} & $\begin{array}{l}\text { Primary cross }{ }^{\mathrm{x}} \\
(\% \mathrm{wt} \text { increase })\end{array}$ & $\begin{array}{l}\text { Reciprocal cross } \\
\text { (\% wt increase) }\end{array}$ & $\begin{array}{l}\text { Primary cross } \\
(\% \text { wt increase })\end{array}$ & $\begin{array}{l}\text { Reciprocal cross } \\
\text { (\% wt increase) }\end{array}$ \\
\hline NC84173 & Fla. $8000^{\mathrm{F}}$ & 0.15 & 0.12 & 0.51 & 0.47 \\
\hline Fla. 7776 & Fla. $8059^{\mathrm{S}}$ & 0.10 & 0.09 & $0.52^{\mathrm{w}}$ & 0.25 \\
\hline Fla. 7776 & Fla. $7777^{\mathrm{s}}$ & $0.06^{\mathrm{w}}$ & 0.15 & 0.45 & 0.20 \\
\hline NC84173 & Fla. $8059^{\mathrm{S}}$ & 0.06 & 0.09 & 0.54 & 0.53 \\
\hline NC84173 & Fla. $7777^{\mathrm{S}}$ & 0.05 & 0.13 & 0.55 & 0.45 \\
\hline Fla. 7946 & Fla. $8059^{\mathrm{S}}$ & 0.08 & 0.07 & 0.27 & 0.34 \\
\hline Fla. 7946 & Fla. $7777^{\mathrm{s}}$ & 0.14 & 0.12 & 0.44 & 0.38 \\
\hline Fla. 7946 & Fla. $8000^{\mathrm{S}}$ & 0.09 & 0.05 & 0.37 & 0.28 \\
\hline Fla. 8059 & Fla. $8000^{\mathrm{S}}$ & 0.14 & 0.07 & 0.52 & 0.64 \\
\hline
\end{tabular}

$\overline{\mathrm{z}}$ (Weight increase/initial weight) $\times 100$.

"Low-absorption parent is listed first; superscript " $F$ " indicates the parents are significantly different during the fall; superscript " $\mathrm{S}$ " indicates the parents are significantly different during the spring determined by Duncan's multiple range test at $P \leq 0.05$.

xPrimary cross has the lower water absorption parent as the female, while the reciprocal cross has the higher water absorption parent as the female. ${ }^{\mathrm{w}}$ Amount of water absorbed by the reciprocal hybrids is significantly different as determined by the contrast procedure using the percentage data transformed by the arcsine square root at $P \leq 0.05$.

${ }_{\mathrm{ND}}^{\mathrm{ND}}$ indicates no seed available. 
percentage weight increases of 0.100 in the fall and 0.400 in the spring, which are very close to their midparent values of 0.095 and 0.425 , respectively. Hybrids from two high-absorption parents had percentage weight increases of 0.11 in the fall and 0.49 in the spring, which are fairly similar to the respective percentage weight increases of their parents.

Because environment is important to absorption levels, it is suggested that parent lines be tested several times, preferably in different seasons or locations with replication to accurately discern water absorption levels. From our results, low-absorption lines like 7946, 7776, and NC84173 may change rankings with little statistical difference between them, but when tested over three seasons they would not be confused with highabsorption lines like 7777, 8059, and 8000. Yet, testing these lines over three seasons provides a better assessment than testing over only one season. In Fall 2005, for instance, even differences between low- and high-absorption lines were not so apparent. Also in Fall 2005, Smith et al. (2007) tested a lowabsorption hybrid vs. a high-absorption hybrid but were unable to obtain statistical differences between the two at $2 \mathrm{~h}$ after harvest, the time frame for the present work due to high variability within the hybrid cultivars. It is not known why the Fall 2005 absorption was relatively low and perhaps variable, but it could relate to the low temperatures incurred before and during the harvest time. This should be studied in future experiments. Commercially, problems with soft rot occur during warmer seasons rather than cooler ones; this could be related to less water absorption occurring in cool weather but also to the favorable conditions for pathogen growth in the field under warm, wet conditions (Mahovic et al., 2007).

Although properly assessed parent lines preclude the need to do a lot of hybrid testing, it is suggested that breeders test hybrids of interest before release to verify that they have the predicted water-absorption levels. Furthermore, reciprocal differences would not be predicted based on the present results, but because some reciprocal differences were obtained, it might be worthwhile for hybrids of interest to be tested reciprocally to see if there was a consistent advantage in one direction or the other. Whereas our results do not suggest that there would be reciprocal differences, there were in fact some significant differences as opposed to a clearer situation where no reciprocal differences were found. As for the hybrids we tested, two are currently grown fresh-market cultivars. 'Solar Fire' $(7946 \times$ 7776) and 'Escudero' (7946 × NC84173) consistently absorbed lower amounts of water over both seasons, which is in agreement with what would be predicted from their parental performance and from previous work (Bartz and Scott, 2005; J.A. Bartz and J.W. Scott, unpublished).

Finally, our analysis indicated the type of gene action conferring low stem scar absorption but not the number of genes involved. Experience suggests a low gene number because testing water absorption is often done only on advanced germplasm that has been selected for other attributes. Low water absorption has been found in many lines that were not directly selected for this trait, making it highly unlikely that a large number of genes control water absorption. Possibly, low water absorption has been selected indirectly by an association with another desirable trait that has been selected. However, what this might be has not been apparent. It does not seem related to common disease resistances, pedicel type, firmness, shoulder color, fruit color, or stem scar size (J.W. Scott and J.A. Bartz, personal observations).

\section{Literature Cited}

Bartz, J.A. 1988. Potential for postharvest disease in tomato fruit infiltrated with chlorinated water. Plant Dis. 72:9-13.

Bartz, J.A. 1991. Relation between resistance of tomato fruit to infiltration by Erwinia carotovora subsp. carotovora and bacterial soft rot. Plant Dis. 75(2):152-155.

Bartz, J.A. 2006. Internalization and infiltration, p. 75-94. In: G.M. Sapers, J.R. Gorny, and A.E. Yousef (eds.). Microbiology of fruits and vegetables. CRC Press, Boca Raton, FL.

Bartz, J.A. and J.P. Crill. 1972. Tolerance of fruit of different tomato cultivars to soft rot. Phytopathology 62(9):1085-1088.

Bartz, J.A., J.P. Crill, and C.A. John. 1975. Inheritance of tolerance to Erwinia carotovora in Florida $\mathrm{MH}-1$ tomato. Phytopathology 65(10):1146-1150.

Bartz, J.A. and J.W. Scott. 2005. Water infiltration and postharvest problems in tomato fruit. Proc. Florida Tomato Inst., Univ. Florida Agr. Expt. Sta. PRO 522:20-23.

Bartz, J.A. and R.K. Showalter. 1981. Infiltration of tomatoes by aqueous bacterial suspensions. Phytopathology 71:515-518.

Berger, R.D. and J.A. Bartz. 1982. Analysis of monocyclic pathosystems with Erwinia lycopersicon as the model. Phytopathology 72:365-369.

Crill, P., J.W. Strobel, D.S. Burgis, H.H. Bryan, C.A. John, P.H. Everett, J.A. Bartz, N.C. Hayslip, and W.W. Deen. 1971. Florida MH-1, Florida's first machine harvest fresh market tomato. Fla. Agr. Expt. Sta. Circ S-212.

Griffing, B. 1956. Concept of general and specific combining ability in relation to diallel crossing systems. Aust. J. Biol. Sci. 9:463-493.

Mahovic, M.J., J.A. Bartz, and K.R. Schneider. 2007. Controlling biotic factors that cause postharvest losses of fresh market tomatoes. Hort. Rev. (Amer. Soc. Hort. Sci.) 33:351-391.

Olson, S.M., D.N. Maynard, G.J. Hochmuth, C.S. Vavrina, W.M. Stall, M.T. Momol, S.E. Webb, T.G. Taylor, S.A. Smith, and E.H. Simonne. 2005. Tomato production in Florida, p. 357-375. In: S.M. Olson and E. Simonne (eds.). Vegetable production handbook for Florida. Vance Publishing Corp., Lincolnshire, IL.

Ott, R.L. and M.T. Longnecker. 2004. A first course in statistical methods. Brooks/Cole-Thomson Learning, Belmont, CA.

Scott, J.W. and F.F. Angell. 1998. Tomato, p. 451-475. In: S.S. Banga and S.K. Banga (eds.). Hybrid cultivar development. Narosa Publishing House, New Delhi, India.

Scott, J.W., J.A. Bartz, H.H. Bryan, P.H. Everett, D.D. Gull, T.K. Howe, P.J. Stofella, and R.B. Volin. 1985. Horizon: a fresh market tomato with concentrated fruit set. Fla. Agr. Expt. Sta. Circ S-323.

Scott, J.W., S.M. Olson, H.H. Bryan, T.K. Howe, P.J. Stofella, and J.A. Bartz. 1989. Solar Set: a heat tolerant fresh market tomato hybrid. Fla. Agr. Expt. Sta. Circ S-359.

Scott, J.W., S.M. Olson, T.K. Howe, P.J. Stofella, J.A. Bartz, and H.H. Bryan. 1995. 'Equinox' heat-tolerant hybrid tomato. HortScience 30:647-648.

Showalter, R.K. and J.A. Bartz. 1979. Post-harvest water-intake and decay of tomatoes. Citrus Veg. Mag. 43:728.

Smith, S.M., J.W. Scott, J.A. Bartz, and S.A. Sargent. 2007. Effect of time after harvest on stem scar water infiltration in tomato. HortScience 42(5): $1-4$.

Steel, R.G.D. and J.H. Torrie. 1980. Principles and procedures of statistics: a biometrical approach. 2nd ed. McGraw-Hill, New York. Wei, C.I., T.S. Huang, J.M. Kim, W.F. Lin, M.L. Tamplin, and J.A. Bartz. 1995. Growth and survival of Salmonella montevideo on tomatoes and disinfection with chlorinated water. J. Food Protection 8:829-836.

Zhang, Y., M.S. Kang, and K.R. Lamkey. 2005. Diallel-SAS05: a comprehensive program for Griffing's and Gardner-Eberhart analyses. Agron. J. 97:1097-1106.

Zhuang, R.Y., L.R. Beuchat, and F.J. Angulo. 1995. Fate of Salmonella montevideo on and in raw tomatoes as affected by temperature and treatment with chlorine. Appl. Environ. Microbiol. 61:2127-2131. 